PANIC CITY 
This page intentionally left blank 


\section{PANIC CITY}

CRIME AND THE FEAR INDUSTRIES

IN JOHANNESBURG

MARTIN J. MURRAY 
Stanford University Press

Stanford, California

(C) 2020 by the Board of Trustees of the Leland Stanford Junior University.

All rights reserved.

Portions of this book were previously published in "Policing in Johannesburg after Apartheid," Social Dynamics 39, no. 2 (2013): 210-27. Published by Taylor \& Francis Ltd. Reused by permission.

No part of this book may be reproduced or transmitted in any form or by any means, electronic or mechanical, including photocopying and recording, or in any information storage or retrieval system without the prior written permission of Stanford University Press.

Printed in the United States of America on acid-free, archival-quality paper

Library of Congress Cataloging-in-Publication Data

Names: Murray, Martin J., author.

Title: Panic city : crime and the fear industries in Johannesburg / Martin J. Murray.

Description: Stanford, California : Stanford University Press, 2020. Includes bibliographical references and index.

Identifiers: LCCN 2019019256 (print) | LCCN 2019022135 (ebook) | ISBN 9781503610194 (cloth : alk. paper) | ISBN 9781503611269 (pbk. : alk. paper) | ISBN 9781503611276 (ebook)

Subjects: LCSH: Crime prevention-South Africa-Johannesburg. | Security systems—South Africa-Johannesburg. | Public safety-South AfricaJohannesburg. | Fear of crime-South Africa-Johannesburg.

Classification: LCC HV7434.S62 M87 2020 (print) | LCC HV7434.S62 (ebook) | DDC $364.4096822 / 15-\mathrm{dc} 23$

LC record available at https://lccn.loc.gov/2019019256

LC ebook record available at https://1ccn.loc.gov/2019022135

Cover design by Kevin Barrett Kane

Cover photograph by Felix Lipov

Typeset by Motto Publishing Services in 11/14 Dante MT 